\title{
PEMULIHAN EKOSISTEM PESISIR MELALUI TRASPLANTASI KARANG DAN PEMBUATAN MEJA SEMAI BLOK BETON DI PULAU SARANG KECAMATAN BELAKANG PADANG, KOTA BATAM
}

\section{COASTAL ECOSYSTEM RECOVERY THROUGH CORAL TRANSPLANTATION ON SARANG ISLAND, BELAKANG PADANG DISTRICT, KATA BATAM}

\author{
Ramses $^{1 *}$, Lani Puspita ${ }^{1}$, Wan $\operatorname{Irhan}^{2}$ dan Hamdayani ${ }^{2}$ \\ ${ }^{1}$ Prodi Pendidikan Biologi, Fakultas Keguruan dan Ilmu Pendidikan, Universitas Riau Kepulauan. \\ ${ }^{2}$ Dinas Perikanan Kota Batam \\ ramses.firdaus@gmail.com; lanipuspita@gmail.com; wanikan@gmail.com; \\ upt.kkpkotabatam@gmail.com
}

\begin{abstract}
Abstrak
Pemulihan ekosistem terumbu karang dipandang perlu dilakukan pada kawasan yang telah mengalami degradasi. Kegiatan rehabilitasi ekosistem terumbu karangdapat dilakukan dengan mengembangkan kemampuan masyarakat dan rehabilitasi habitat dengan sentuhan manajemen dan teknologi. Salah satu kegiatan untuk memulihkan habitat alami adalah dengan melakukan transplantasi karang. Kegiatan ini bertujuan untuk melakukan trasnplantasi karang dan pembuatan meja semai blok beton untuk perbaikan ekosistem terumbu karang serta mendorong pemanfaatan ramah lingkungan dan pelestarian sumberdaya terumbu karang serta menumbuh kembangkan ekonomi masyarakat pesisir di lokasi yang diusulkan, sekaligus dapat digunakan sebagai daya tarik wisatawan. Telah dilakukan pelatihan transplantasi karang kepada masyarakat Pulau Sarang, mahasiswa dan pelajar. Telah dipasang 40 maja blok beton untuk penyemaian/penanaman karang trasplantasi. Sudah tertanam stek karang sebanyak 25-30 stek karang pada setiap unit meja semai dengan ukuran meja 1x1 meter. Adanya kegiatan transplantasi akan dapat mempercepat tingkat pemulihan ekosistem terumbu karang yang rusak. Dengan membaiknya kondisi terumbu karang dapat meningkatkan pendapatan masyarakat yang mengelolanya, dari segi wisata bahari maupun meningkatan hasil tangkapan nelayan seiring membaiknya habitat alami sebagai penopang keberlangsungan sumberdaya perikanan.
\end{abstract}

Kata Kunci : Ekosistem pesisir, terumbu karang, transplantasi

\begin{abstract}
Recovery of coral reef ecosystems is deemed necessary in areas that have been degraded. The rehabilitation of coral reef ecosystems can be carried out by developing community capabilities and rehabilitating habitats with a touch of management and technology. One of the activities to restore natural habitat is to do a coral transplant. This activity aims to carry out coral transplantation and the creation of concrete block seedling tables to improve coral reef ecosystems and encourage environmentally friendly use and preservation of coral reef resources and grow the economy of coastal communities in the proposed locations, while also being used as a tourist attraction. Coral transplant training has been carried out to the people of Pulau Sarang, students, and students. 40 concrete block tables have been installed for transplanting coral planting. There are 25-30 coral cuttings embedded in each seedling table unit with a table size of $1 \times 1$ meter. Transplantation activities will be able to accelerate the recovery rate of damaged coral reef ecosystems. With the improvement of the condition of coral reefs, it can increase the income of the people who manage it, in terms of marine tourism and the increase in fishermen's catches as natural habitat improves as a support for the sustainability of fisheries resources.
\end{abstract}


Keywords: Coastal ecosystems, coral reefs, transplants

\section{PENDAHULUAN}

Salah satu pulau yang perpenghuni yang berbatasan langsung dengan perairan internasional adalah Pulau Sarang dan Pulau Mecan. Penduduk Pulau Sarang dan Mecan didiami oleh 516 jiwa penduduk dan hampir $100 \%$ penduduk bermata pencarian nelayan. Kawasan ini memiliki historis sebuah kejayaan, dimana pada mulanya merupakan wilayah pesisir yang memiliki ekosistem yang beragam seperti mangrove, lamun dan terumbu karang dalam kondisi yang masih baik.

Pada saat ini sumberdaya tersebut sudah mengalami kerusakan terutama pada ekosistem terumbu karang. Hal ini terjadi karena katidaktahuan masyarakat dalam pemanfaatan yang berkelanjutan. Salah satunya adalah pengambilan karang alam untuk memenuhi permintaan pasar karang hias dan kebutuhan arang bakau di Singapura dan Malaysia. Menurut Ramses (2018) tingginya permintaan dari pasar Singapura menjadi salah satu pemicu masyarakat melakukan eksploitasi dengan tidak tanggung jawab atau ilegal. Pada kurun waktu tahun 1998-2010, pengambilan karang alam di daerah ini untuk perdagangan ilegal (smaglers) telah berlangsung lama dan sangat massive. Namun demikian, secara legal perdagangan karang dapat dilakukan. Terumbu karang merupakan komoditas ekspor hasil perikanan yang memiliki potensi di pasar lokal maupun internasional dengan harga jual yang tinggi. Hal tersebut yang mendorong perusahaan perikanan membudidayakan terumbu karang untuk dijual dan menghasilkan keuntungan yang tinggi (Yahya dan Andriyono, 2014).

Terumbu karang merupakan salah satu sumberdaya kelautan yang mempunyai beragam nilai dan fungsi antara lain: nilai rekreasi dan ekowisata (penyedia jasa-jasa lingkungan bagi aktivitas rekreasi dan wisata bahari), nilai produksi (sumber bahan pangan, industri, ornamental, dll.) dan nilai konservasi (seperti mendukung proses-proses ekologis dan penyangga kehidupan di daerah pesisir, pengawetan keanekaragaman hayati laut, sumber sedimen pantai (penghasil pantai berpasir) dan melindungi garis pantai dari ancaman abrasi) (Anonim 2013). Dilain sisi, terumbu karang yang ada di Kota Batam semakin hari semakin terdegradasi dan mengalami kerusakan dan sangat mengkhawatirkan. Padahal, potensi terumbu karang Kota Batam jika dikelola dengan baik dapat dijadikan sebagai salah satu destinasi penyelaman dan obyek wisata bahari yang ramai dikunjungi oleh wisatawan, dan 
menguntungkan Kota Batam. Berdasarkan kriteria baku kerusakan terumbu karang pada Keputusan Menteri Negara Lingkungan Hidup No. 4 Tahun 2001 Tanggal 23 Februari 2001, ditetapkan berdasarkan prosentase luas tutupan terumbu karang yang hidup, dimana kriteria rusak 0-24,9\% tutupan karang hidup.

Untuk meningkatkan kondisi dan pemulihan ekosistem terumbu karang tersebut dipandang perlu adanya upaya-upaya seperti pemeliharaan habitat, rehabilitasi ekosistem yang mengalami degradasi dan pengembangan obyek dengan sentuhan manajemen dan teknologi. Salah satu upaya untuk memulihkan habitat alami pada kawsan ini adalah dengan melakukan kegiatan transplantasi karang. Menurut Radu, et, al., (2012) pengelolaan terumbu karang pada dasarnya merupakan suatu proses pengontrolan tindakan manusia agar pemanfaatan sumberdaya alam dapat dilakukan secara bijaksana dengan mengindahkan kaidah pelestarian lingkungan. Terumbu karang merupakan ekosistem perairan yang khas terdapat di daerah tropis yang memiliki produktivitas dan keanekaragaman biota yang tinggi. Ekosistem terumbu karang memiliki fungsi yang penting bagi kehidupan ekologi pantai dan pesisir, terutama sebagai sumber nutrien bagi habitat yang berada di sekitar ekosistem ini. Transplantasi karang memanfaatkan kemampuan regenerasi karang secara aseksual (Yunus, et al., 2013).

Transplantasi karang dilakukan bertujuan untuk pelestarian dan perbaikan ekosistem, perlindungan terhadap erosi pesisir dan berbagai kegiatan yang bersifat penelitian (Kordi, 2010). Selanjutnya Haris, (2011) menjelaskan bahwa untuk menekan dan memulihkan kerusakan terumbu karang, perlu dilakukan tindakan pengendalian agar kondisinya tidak semakin parah. Salah satu cara untuk mengendalian laju kerusakan tersebut adalah dengan cara melakukan transplantasi karang. Transplantasi karang adalah mendempetkan anakan karang pada suatu substrat yang keras. Menurut Clark dan Edwards (1995) dalam Aditiyana (2012), penanggulangan kerusakan atau rehabilitasi dapat dilakukan dengan transplantasi. Hal ini merupakan suatu langkah awal dalam memulihkan sekaligus menjaga kelestarian terumbu karang. Transplantasi karang adalah salah satu upaya rehabilitasi yang dapat diterapkan untuk mempercepat proses pemulihan terumbu karang.

Tujuan kegiatan ini adalah melakukan kegiatan trasnplantasi karang dan pembuatan meja semai dengan mengunakan blok beton. Sedangkan sasaran dari Kegiatan ini adalah pengembangan dan penataan lingkungan pesisir dan laut yang berpotensi dan berorientasi 
ekonomi dan ekologis melalui perbaikan ekosistem terumbu karang. Selain itu, mendorong pemanfaatan ramah lingkungan dan pelestarian sumberdaya terumbu karang serta menumbuh kembangkan ekonomi masyarakat pesisir di lokasi yang diusulkan, sekaligus dapat digunakan sebagai daya tarik wisatawan.

\section{METODOLOGI}

Kegiatan dilaksanakan pada buan Mei-September 2015. Tempat pelaksanaan kegiatan dilaksanakan di komunitas masyarakat Pulau Sarang, Kelurahan Sekanak Raya, Kecamatan Belakang Pandang, Kota Batam. Sedangkan lokasi pemasangan meja transplantasi karang adalah Terumbu Berendam perairan Pulau Layang pada koordinat N 0107'58.0" E $103^{0} 51$ '14.4”. Perairan Pulau Layang khususnya area "Terumbu Berendam”, dinilai sangat memadai untuk penyemaian dan pertumbuhan karang transplantasi. Secara spesifik lokasi ini adalah perairan pantai zona sublitoral pada kedalaman 3- $6 \mathrm{~m}$ (Kambey, 2013). Selain kedalaman, aspek lingkungan lainnya yang menjadi pertimbangan adalah adalah dasar berpasir/raber (tidak berlumpur), arus pasang dan surut kecepatan sedang, dekat dengan karang alami. Selain aspek lingkungan, aspek efektifitas dan efisiensi pemeliharaan dan perawatan paska kegiatan oleh masyarakat relatif dekat dari pemukiman pulau sarang dan mudah dijangkau.

Pelaksanaan kegiatan dilakukan melalui beberapa metode pendekatan diantaranya : Pertemuan dan diskusi (community meeting); Training/pelatihan pembuatan transplantasi karang; Praktek/implementasi (pembuatan media tanam, pembuatan meja tanam, Penurunan dan penataan mejatanam dan penyemainan karang transplantasi.

\section{PEMBAHASAN}

\section{Sosialisasi Kegiatan}

Sosialisasi kegiatan di masyarakat dilakukan melalui pertemuan-pertemun. Pertemuan dikemas dalam bentuk penyuluhan dan penyadartahuan masyarakat akan pentingnya pelestarian ekosistem pesisir khususnya ekosistem terumbu karang. Hal ini dilakukan untuk mendapatkan dukungan dari masyarakat dan pemerintahan lokal, setra untuk pelibatan masyarakat dalam perencanaan, pelaksanaan dan keperlanjutan kegiatan paska kegiatan. 
Secara khusus kegiatan sosialisasi bertujuan antara lain: 1). Diskusi antar komunitas dalam rangka persiapan masyarakat dan penetaan kawasan kelola; 2). Sosialisasi program, konsultasi, dan koordinasi dengan masyarakat di lokasi; 3. Penggalangan dukungan tingkat local (kepada tokoh masyarakat, pemerintahan kelurahan, dan dinas instansi terkait) untuk sinkronisasi program dan ruang kelola.

\section{Pelatihan Pembuatan Transplantasi Karang}

Pelatihan transplantasi karang bertempat di Pulau Sarang melibatkan masyarakat, mahasiswa dan pelajar. Penyampaian materi dan praktek dilakukan di lapangan terbuka. Untuk memenuhi bahan pelatihan di sediakan meja semai, media tanam dan bibit karang sebagai bahan praktek. Materi yang disampaikan antara lain: pemelihan koloni karang yang akan dijadikan stak karang, pembuatan media tanam, mengeleman/perekatan stak karang pada media tanam dan trik-trik lainnya agar trasplantasi karang yang dilakukan tidak mengalami kematian baik karena cahaya dan kekeringan, maupun disebabkan oleh tertutupnya pori-pori karang akibat perekat yang digunakan. Pada pelatihan ini perekat digunakan semen dicampur air laut.

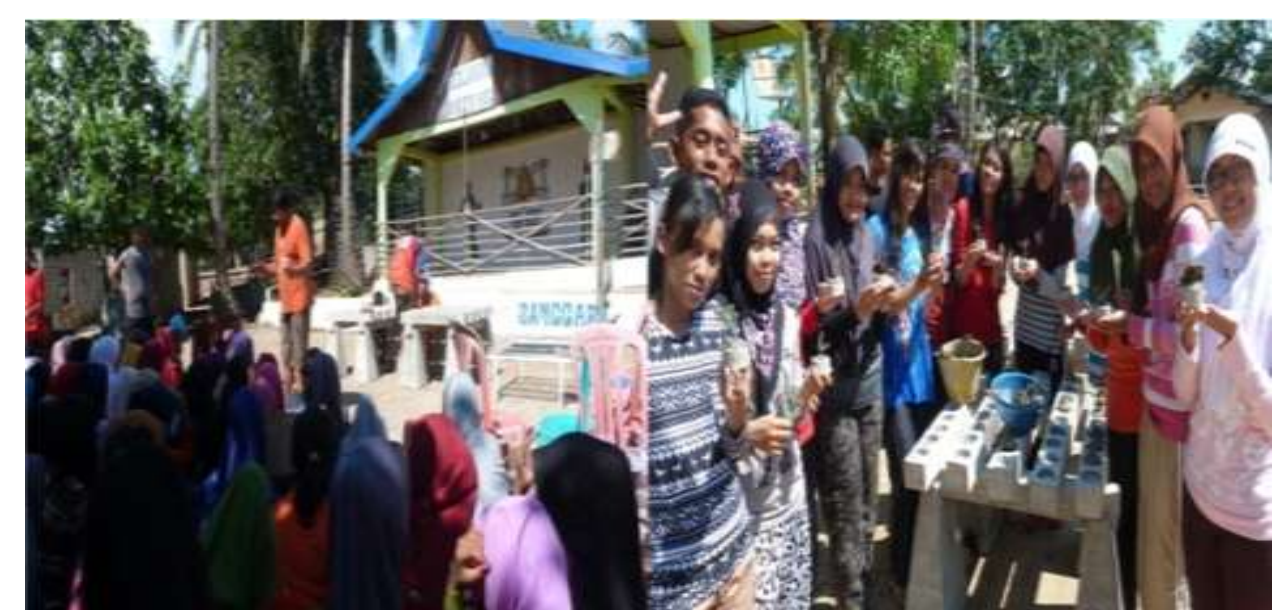

Figur 1. Pelatihan transplantasi bagi masyarakat, mahasiswa dan pelajar

Transplantasi terumbu karang menurut Yahya dan Andriyono (2014) dapat dilakukan menggunakan substrat semen sebagai media hidupnya. Fragmen karang hidup hasil pemotongan dari induk terumbu karang di tanam di substrat semen tersebut menggunakan pelekat campuran semen dan air laut. Bentuk media tanam dan bibit yang sudah direkatkan dengan media tanam dapat dilihat pada Gambar 3 berikut ini. 


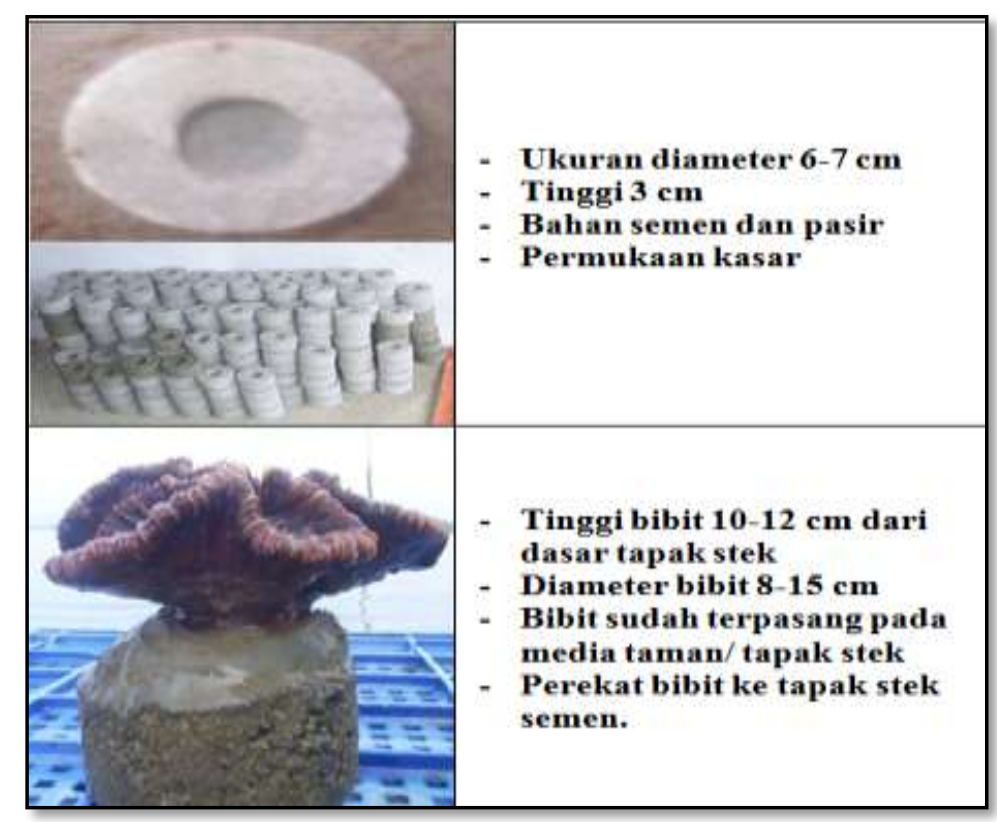

Figur 2. Media tanam/tapak stek dan stek karang siap semai

\section{Pembuatan Meja Semai Blok Beton}

Dalam pembuatan media semai trasplantasi, harus dipersiapkan secara matang agar memenuhi stndar kekuatan yang di inginkan. Perencanaan dan perkiraan beban masing-masing komponen meja semai seperti; balok galur, tapak dan umpak harus memiliki berat yang dapat diangkat secara manual (tenaga manusia) agar operasional penurunannya ke dasar laut efisien dan efektif. Pemilihan blok beton sebagai media semai transplantasi karang dimaksudkan karena meja blok beton memiliki keunggulan tersendi dari meida lainnya seperti meja paralon ataupun meja dari besi yang juga umum digunakan dalam proses transplantasi karang. Keunggulan meja blok beton sebagai media semai trasplantasi karang adalah 1). Dapar sekaligus sebagai artificial reef (terumbu buatan) dan habitat baru bagi biota laut; 2). Baik untuk tujuan pengunaan jangka waktu lama; 3). Kokoh dan tidak mudah terbawa arus; 4). Mempercepat penempelan polip karang secara alami (sekaligus menyediakan media penempelan polip karang alam). 5). Mempercepat proses regenerasi dan pemulihan habtat. Berikut adalah tahapan pembuatan meja semai blok beton:

\section{Persiapan}

1. Peralatan Kerja; Peralatan kerja yang dibutuhkan untuk kontruksi media tranplantasi tidak berbeda dengan peralatan pembuatan bangunan lazimnya. Kerena pada 
prinsipnya pembuatan media transplantasi ini adalah pekerjaan fisik. Namun pada tahapan berikutnya seperti penyusunan dan penataan media didasar perairan di butuhkan perlengkapan kusus tambahan seperti peralatan scuba dan sarana transportasi angkutan laut.

2. Pengadaan Bahan; Bahan yang digunakan berupa semen, pasir, batu dan besi.

3. Persiapan Tenaga Kerja; Tenaga kerja terdiri dari tenaga kerja bangunan (batu dan kayu) serta tenaga pengangkatan/pengangkutan dan penyelaman.

4. Persiapan Lokasi Kerja; Lokasi kerja ditempatkan di Pulau Sarang. Persiapan lokasi kerja akan menentukan efektifitas dan efesiensi pekerjaan, dimana lokasi kerja harus diupayakan sedekat mungkin dengan lokasi pemasangan guna memudahkan dan memperingkas jarak angkut media setelah dicetak.

\section{Pembuatan meja semai blok beton}

1. Pembuatan Bakesting (cetakan/mal)

Sebelum dilakukan pencetakan media transplantasi, terlebih dahulu dilakukan pembuatan cetakan sesuai ukuran dan disaign media yang diperlukan.

2. Pencetakan Media

Sebelum pencetakan bahan dan peralatan sudah disiapkan terlebih dahulu. Setelah bakesting disiapkan, selanjutnya dilakukan pengecoran sesuai dengan kebutuhan. Pencetakan media transplantasi pada pekerjaan ini adalah sebanyak 45 media trasnplantasi dengan spesifikasi teknis, sebagai berikut:

- Ukuran meja transplantasi adalah $1 \times 1$ meter yang terdiri dari balok meja trasplntasi, balok galur dan pondasi umpak.

- 1 unit meja transplantasi terdiri dari 8 buah balok meja transplantasi, 2 buah balok galur dan 4 buah pondasi umpak

- 1 unit meja trasplantasi pemasangan stek karang sebanyak 25-30 stek karang.

- Satu balok tanam dibuat 10 lobang (sebanak mungkin) berukuran sebeh besar dari media tanam agar media tanam masuk. Banyaknya lobang ( \pm 50 logang/meja) dari jumlah stek karang dalam satu meja (25-30 stek/meja), bertujuan untuk memudahkan mengatur jarak penyemaian, agar pertumbuhan antar spesies tidak terganggu. 


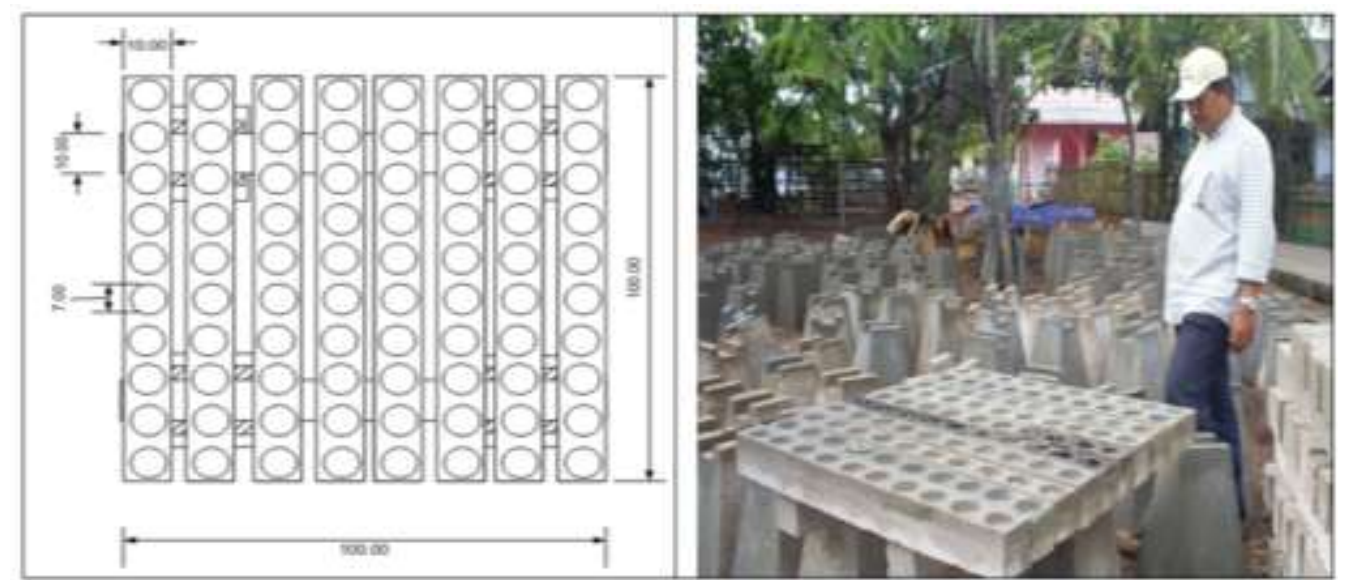

Figur 3. Disain dan model maja blok beton sebagai media semai bibit karang hasil transplantasi

\section{Penurunan Dan Pemasangan Meja Semai Blok Beton}

Sebelum meja transplantasi diangkut atau di mobilitasi ke lokasi pemasangan, terlebih dahulu dilakukan persiapan lokasi (dasar perairan) untuk menentukan posisi penyusunan meja semai transplantasi. Setelah posisi penyusunan ditata sedemikian rupa, barulah dilakukan pengangkutan komponen meja blok beton secara bertahap ke lokasi pemasangan. Pekerjaan ini dilakukan diatas periaran dan di bawah perairan. Penurunan dilakukan bertahap per satu set komponen meja semai karang yang diturunkan pada titik-titik di bawah laut pemasangan yang telah ditentukan. Setelah 2 minggu setelah di turunkan dan ditata di dasar perairan barulah dilakukan persiapan penyemaian. Hal ini bertujuan agar pengaruh semen dari blok beton ini terhadap hewan karang dapat di kurangi agar tidak menumbulkan kematian pada stek karang.

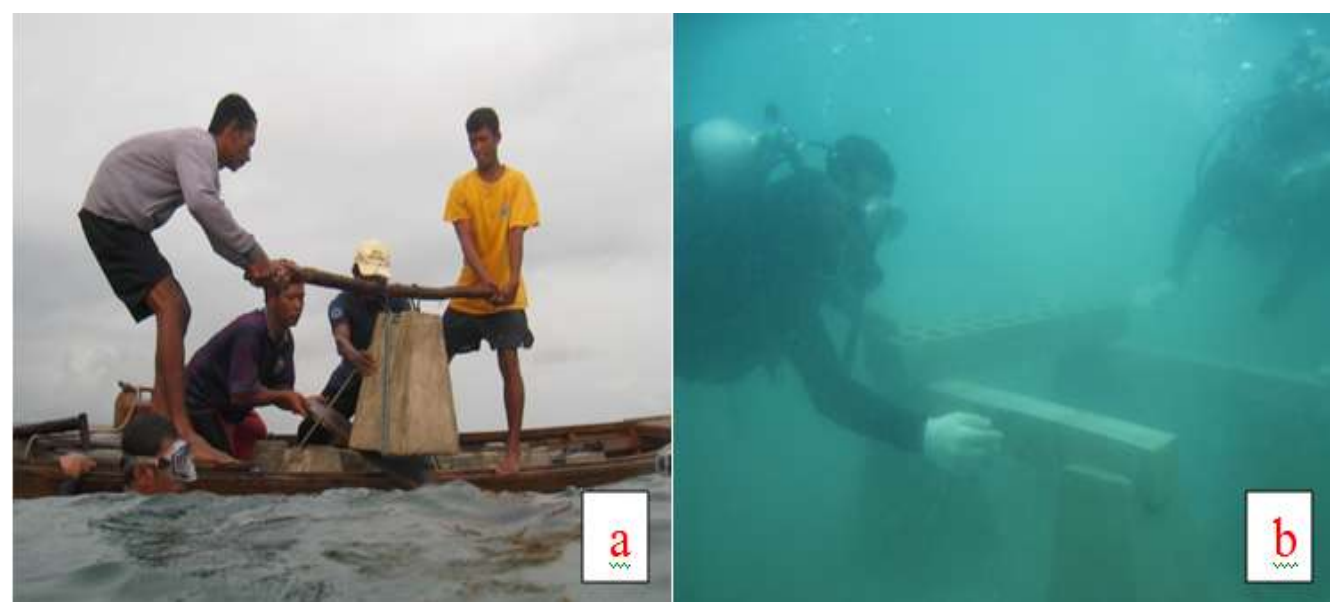

Figur 4. Proses penurunan dan penyusunan tata letak meja semai 


\section{Penyemaian Bibit Karang (stek karang) Hasil Transplantasi}

Tahap akhir dari proses ini adalah penyemaian stek karang yang telah dipersiapkan sebelumnya. Penyiapan stek karang dikakuakan minimal 2 minggu sebelum penurunan meja semai. Arinya stek karang transplan tasi baru bisa di semai pada meja karang setelah 1 bulan setelah penyetekan. Hal ini dilakukan untuk meminimalisir kematian pada setelah menyemaian. Hanya stek karang trasplantasi yang hidup atau baik yang akan disemai. Biasanya, stek karang telah melewati masa stres paska penyetekan/pemotongan dan perekatan pada media tanam setelah 2 minggu. Oleh karenanya penyemaian dilakukan setelah 2-4 minggu setelah penyetekan. Induk sebaiknya diambil dari lingkungan sekitar, agar adaptasi terhadap perairan cepat berlangsung, dan mengurangi stres pada karang karena adanya penyesuaian lingkungan.

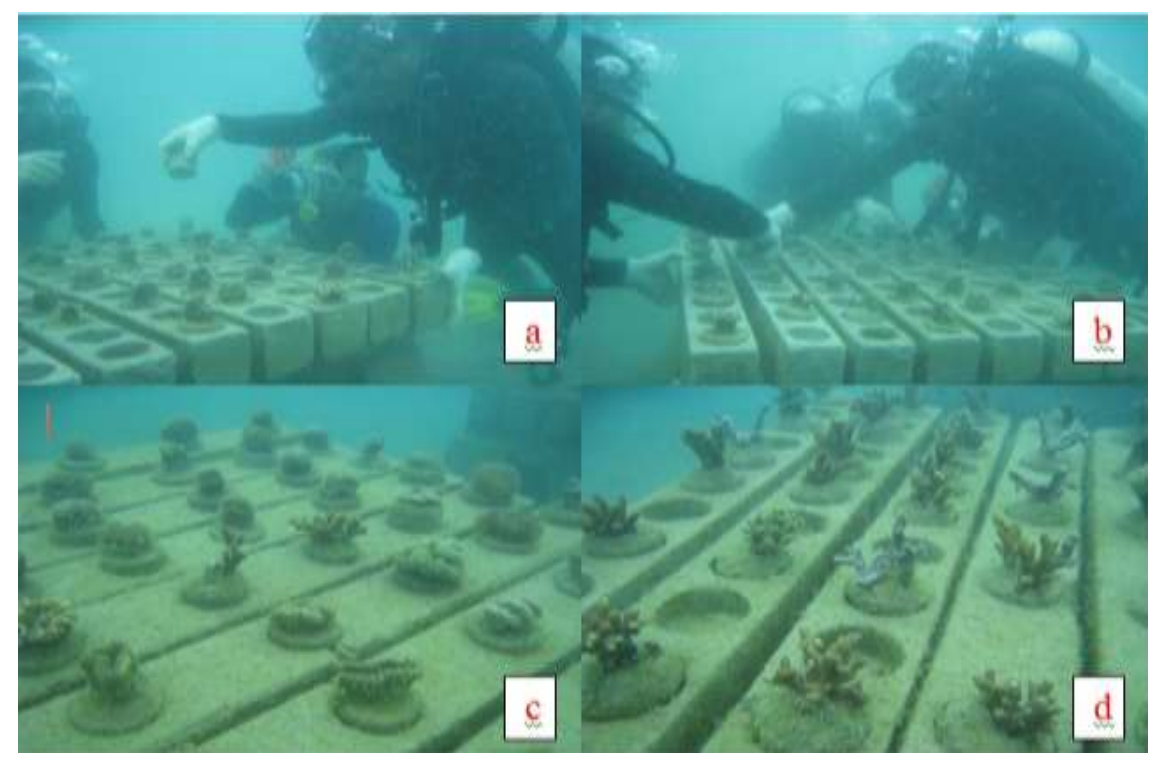

Figur 5. Proses penyemaian bibit karang (a dan b) dan kondisi bibit setelah satu bulan penyemaian (c dan d)

\section{KESIMPULAN DAN SARAN}

Telah dilakukan pelatihan transplantasi karang kepada masyarakat Pulau Sarang, mahasiswa dan pelajar. Telah dipasang 40 maja blok beton untuk penyemaian/penanaman karang trasplantasi. Sudah tertanam stek karang sebanyak 25-30 stek karang pada setiap unit meja semai dengan ukuran meja 1x1 meter. Dengan adanya kegiatan transplantasi akan dapat mempercepat tingkat pemulihan ekosistem terumbu karang yang rusak. Dengan membaiknya 
kondisi terumbu karang dapat meningkatkan pendapatan masyarakat yang mengelolanya, dari segi wisata bahari maupun meningkatan hasil tangkapan nelayan seiring membaiknya habitat alami sebagai penopang keberlangsungan sumberdaya perikanan. Kesadaran dan prilaku konservasi masyarakat mulai tumbuh dan berkembang. Diharapkan kegiatan ini dapat menjadi contoh restorasi ekosistem terumbu karang dan menjadi model pemberdayaan komunitas masyarakat di daerah perbatasan.

Kesadaran yang mulai tumbuh dalam masyarakat, hendaknya terpelihara dengan melibatkan masyarakat dalam berbagai kegiatan konservasi. Kegiatan konservasi sumberdaya pesisir seperti karang, lamun dan mangrove juga harus dikembangkan dan diperluas lagi.

\section{DAFTAR PUSTAKA}

Aditiyana, I, A., 2012. Analisis Laju Pertumbuhan Dan Tingkat Keberhasilan Transplantasi Karang Stylophra pistillata Dan Pocillopora verrucosa Di Perairan Pulau Karya Kepulauan Seribu. (Skripsi). Institut Pertanian Bogor. Bogor

Anonim, 2013. Delapan Fungsi Transplantasi Karang. By kawan kurnia tour travel Wednesday, February 13, 2013. http://www.tourkarimunjawa.net/2013/02/delapanfungsi-transplantasi-karang.html

Haris, A., 2011. Jurnal Omni Akuatika-Transplantasi Karang Acroporidae. Jurnal Penelitian Perikanan Dan Kelautan, 10(12): 1-42.

Kordi, K. M. G. H., 2010. Ekosistem Terumbu Karang: Potensi, Fungsi dan Pengelolaan. Rinela Cipta. Jakarta. 212 hlm.

Kambey, A. D., 2013. The Growth of Hard Coral (Acropora sp.) Transplants in Coral Reef of Malalayang Waters, North Sulawesi, Indonesia. Jurnal Ilmiah Platax. Vol. 1(4): 196203. http://ejournal.unsrat.ac.id/index.php/platax

Keputusan Menteri Negara Lingkungan Hidup No. 4 Tahun 2001 Tanggal 23 Februari 2001 Tentang Kriteria Baku Kerusakan Terumbu Karang. https://arsipskpd.batam.go.id/batamkota/skpd.batamkota.go.id/dampaklingkungan/files/ 2012/01/Kepmen-LH-no.4-th-2001-Terumbu-Karang.pdf

Yahya, M. R., dan Andriyono, S. 2014. Transplantasi Terumbu Karang Oleh CV. Putra Pelangi Samudra, Denpasar Bali. Technical Report. January 2014. https://www.researchgate.net/publication/288828203 
Radu, L., Prianto, A. L., Tahir, M. M., 2012. Good Coral Governance (Inovasi Pengelolaan Terumbu Karang) Kabupaten Wakatobi. Otoritas. Vol. II, (2): 165-179.

Ramses. 2018. Kondisi dan Keragaman Karang Hias di Perairan Pulau Sarang dan Sekitarnya, Kecamatan Belakang Padang, Kota Batam. Simbiosa, 6(2): 57-66.

Yunus, B.H., Wijayanti, D.P., dan Sabdono A., 2013. Transplantasi Karang Acropora Aspera dengan Metode Tali di Perairan Teluk Awur, Jepara. Buletin Oseanografi Marina. vol. 2(3): 22-28. https://doi.org/10.14710/buloma.v2i3.6947 


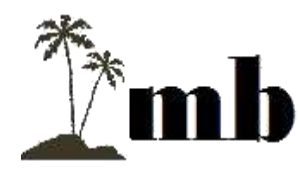

Minda Baharu, Volume 3, No 1 Juli 2019

Doi. 10.33373/jmb.v3i1.1862

https://www.journal.unrika.ac.id/index.php/MNDBHRU

\section{P-ISSN 2656-0631; E-ISSN 2614-5944}

Hal. 42-58

Lampiran 1. Jenis Karang Keras dan Lunak hasil Transplantasi di Perairan Pulau Sarang, Kota Batam

\section{A. Karang Keras (Hard Coral)}

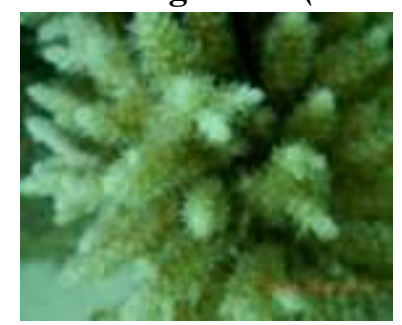

Acropora milepora

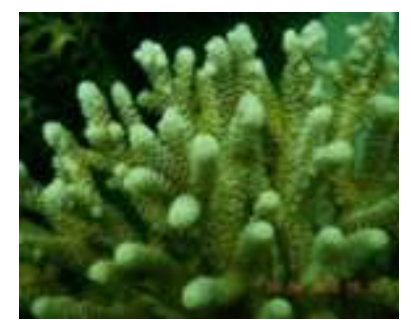

Acropora palifera

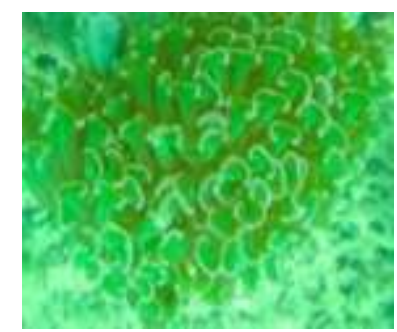

Euphylia ancora

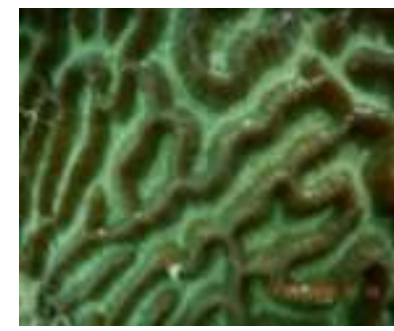

Symphyllia recta

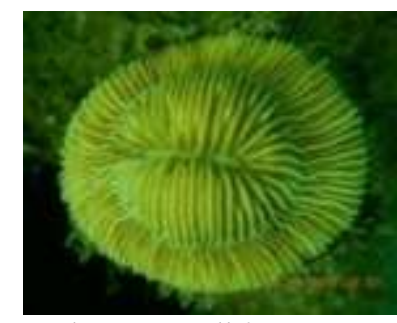

Cycloseris patelliformis

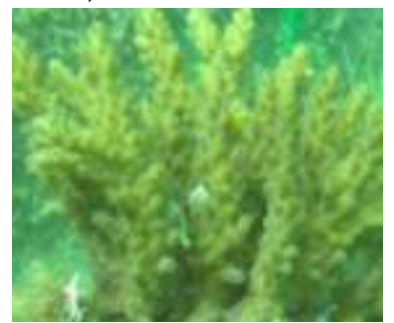

Acropora robusta

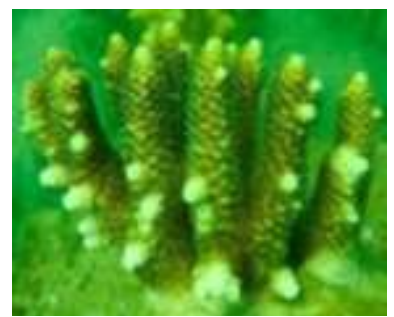

Acropora humilis

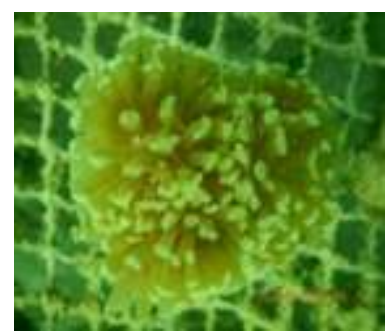

Euphyllia paraancora

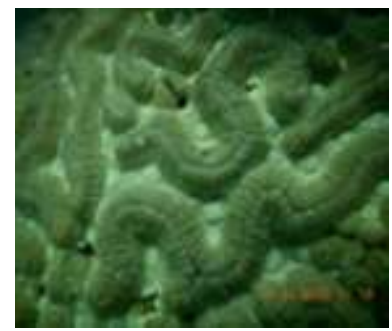

Symphyllia agaricia

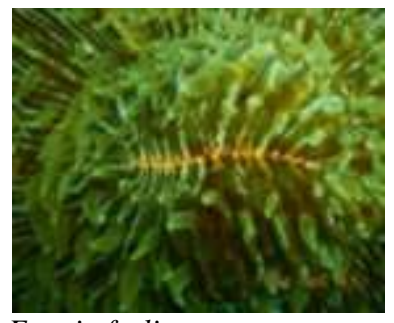

Fungia fralinae

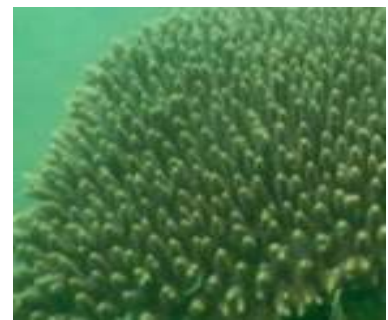

Acropora tenuis

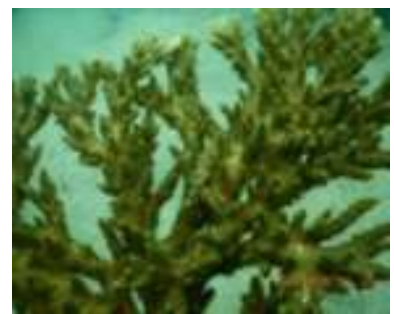

Acropora sarmentosa

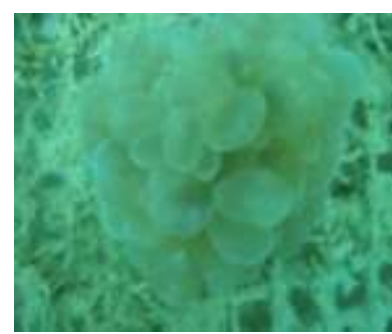

Plerogyra sinuosa

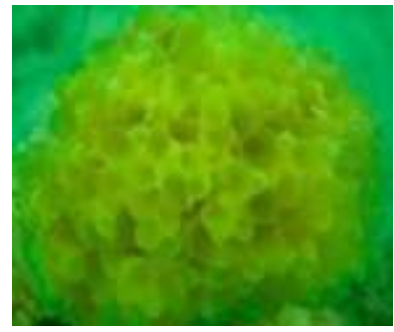

Physogyra lichtensteini

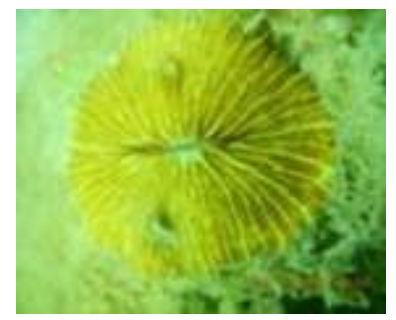

Cycloseris patelliformis

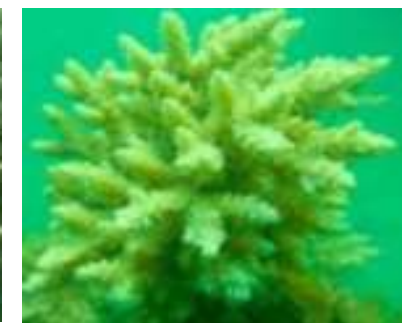

Acropora donei

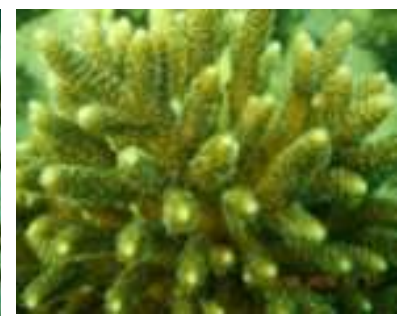

Acropora striata

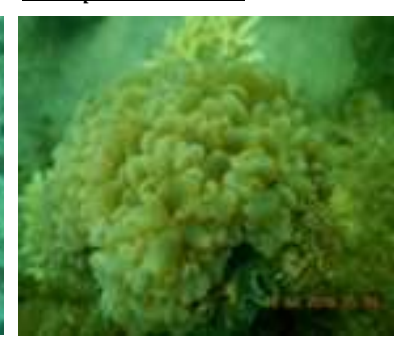

Plerogyra spl

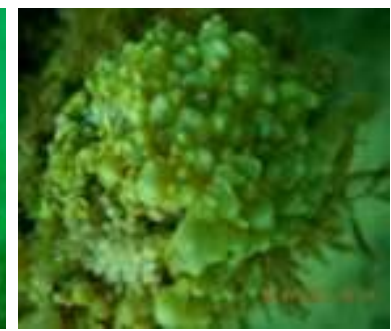

Physogyra spl

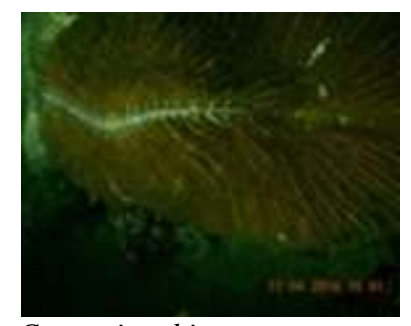

Ctenactis echinata 


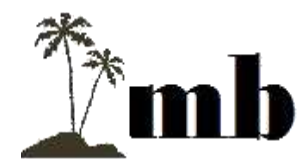

Minda Baharu, Volume 3, No 1 Juli 2019

Doi. 10.33373/jmb.v3i1.1862

Hal. 42-58

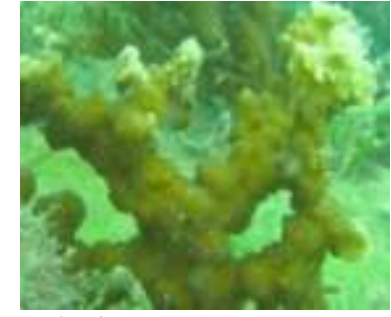

Stylophora spl

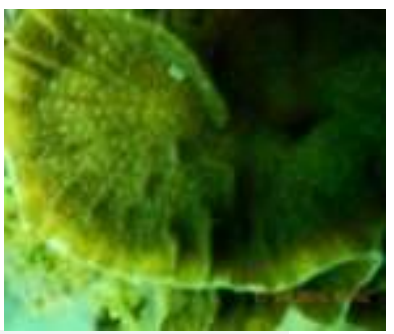

Montipora tuberculosa

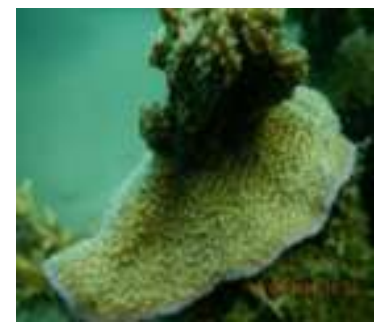

Montipora sp1

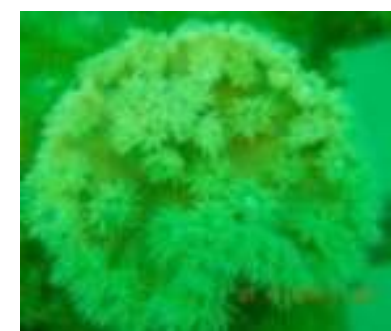

Tubinaria bifrons

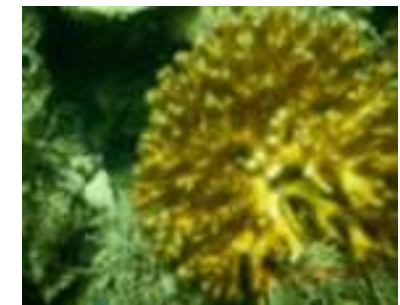

Pocillopora damicornis

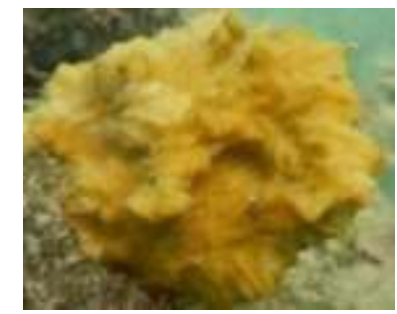

Leptoseris spl

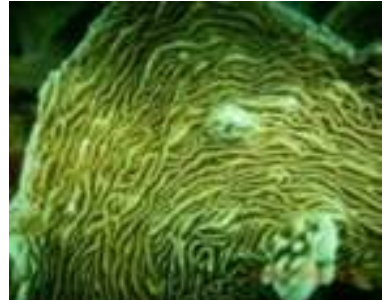

Pachyseris rugosa

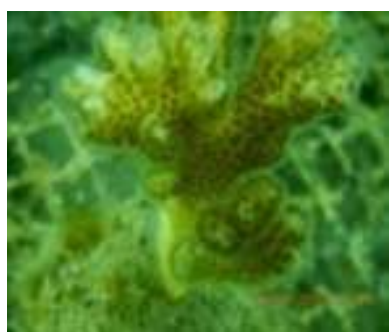

Palauastrea ramosa

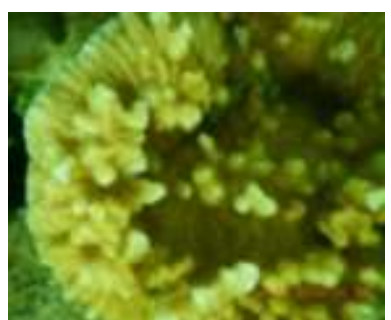

Montipora capricornis

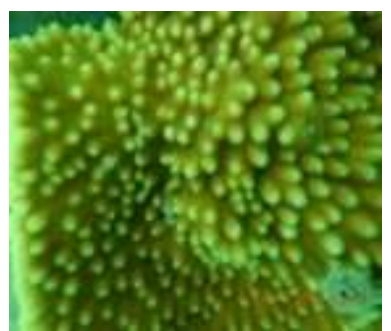

Turbinaria mesenterina

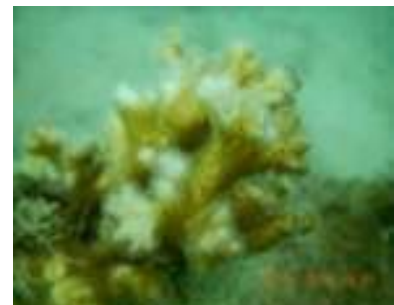

Palauastrea ramosa

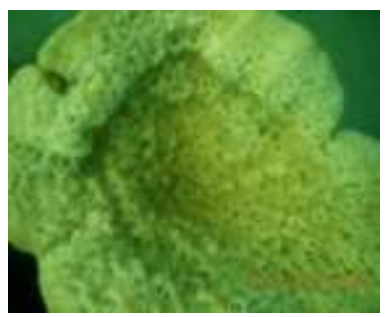

Podabacia sina

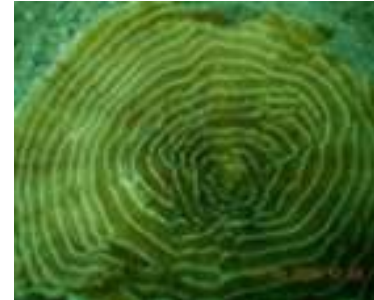

Pachyseris speciosa

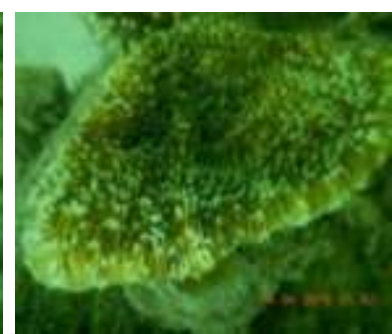

Montipora foliosa

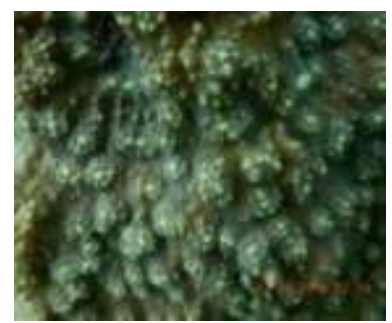

Montipora tuberculosa

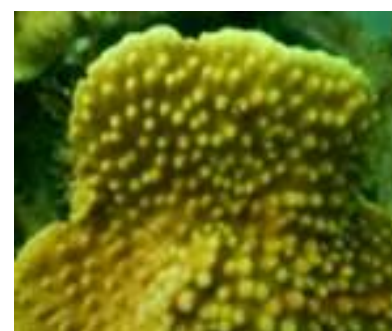

Turbinaria stellulata

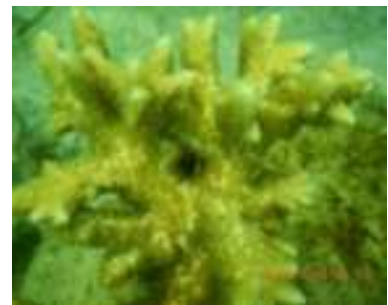

Hydnophora spl

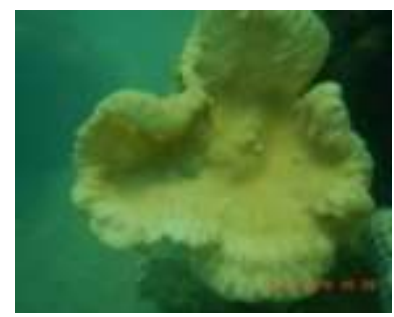

Merulina ampliata

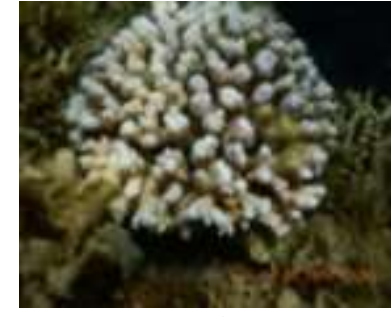

Psammocora spl

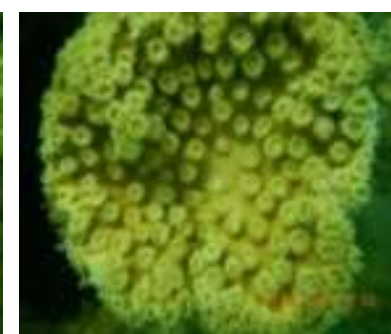

Turbinaria peltata

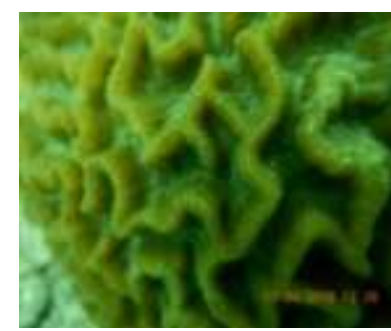

Oulophyllia crispa

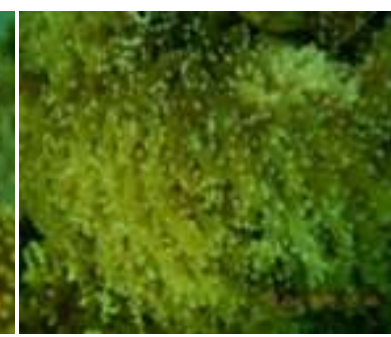

Euphylia divisa

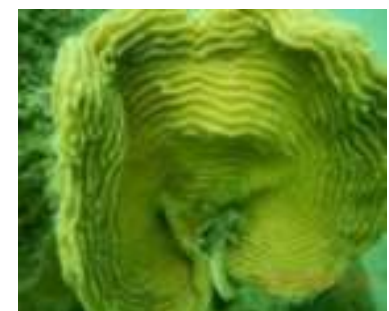

Pachyseris speciosa

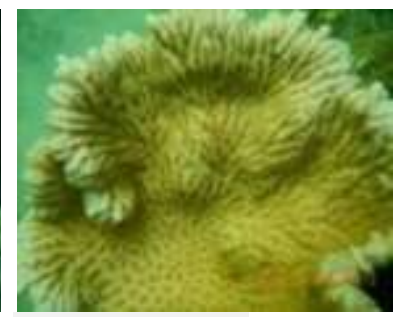

Merulina ampliata 


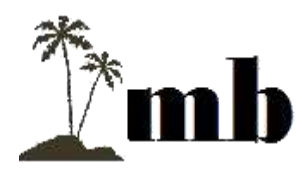

Minda Baharu, Volume 3, No 1 Juli 2019

Doi. 10.33373/jmb.v3i1.1862

https://www.journal.unrika.ac.id/index.php/MNDBHRU

P-ISSN 2656-0631; E-ISSN 2614-5944

Hal. 42-58

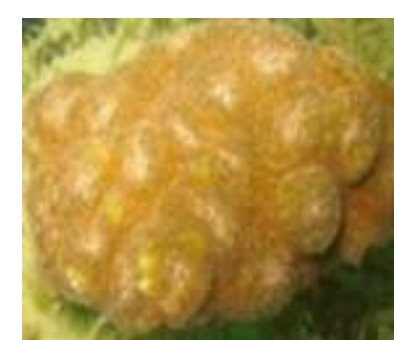

Acanthastrea echinata

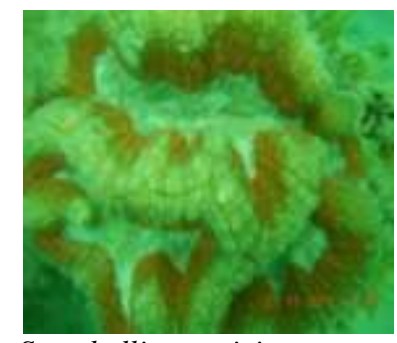

Symphyllia agaricia

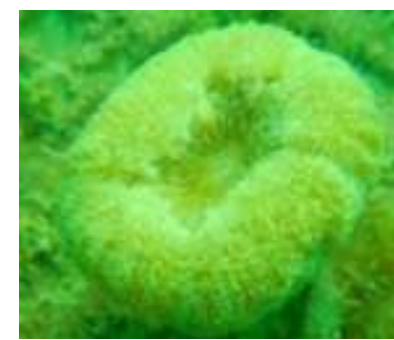

Symphyllia sp4

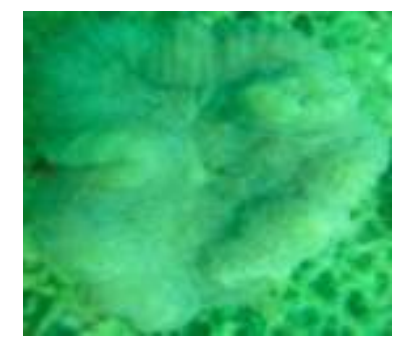

Symphyllia sp5

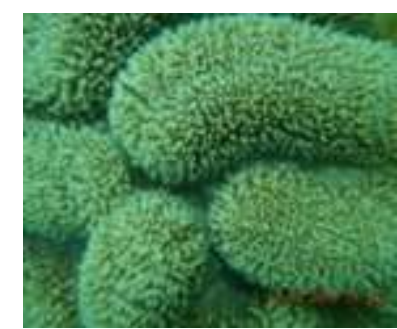

Lobophyllia robusta

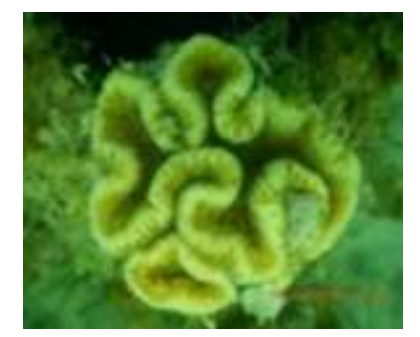

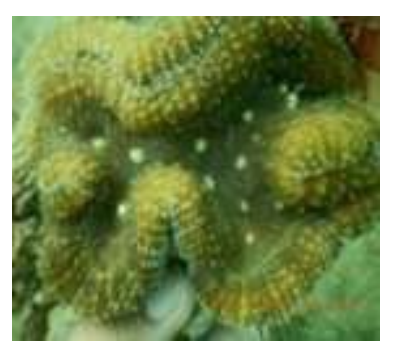

Wellsophyllia radiata

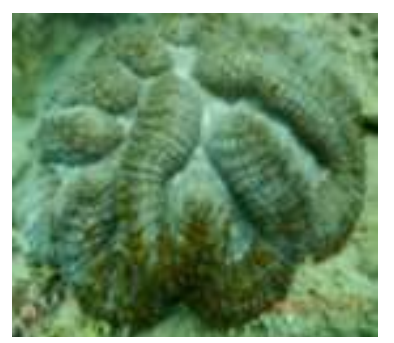

Symphyllia agaricia

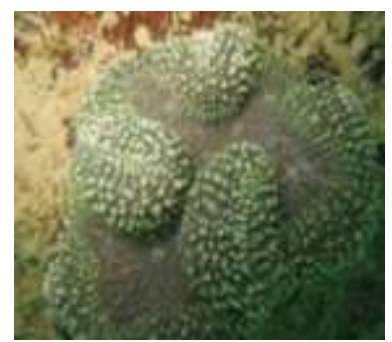

Symphyllia spl

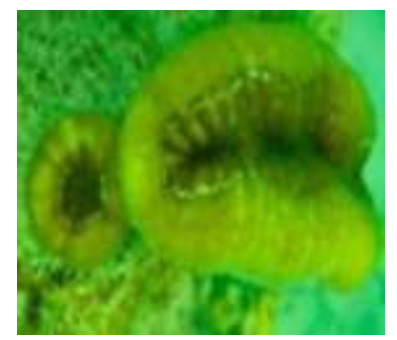

Mussa angulosa

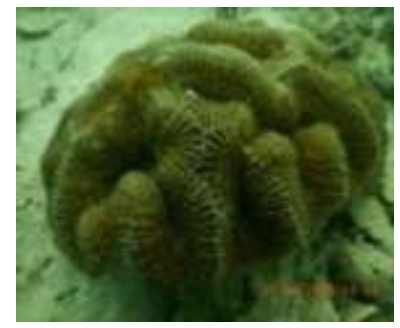

Lobophyllia corymbosa

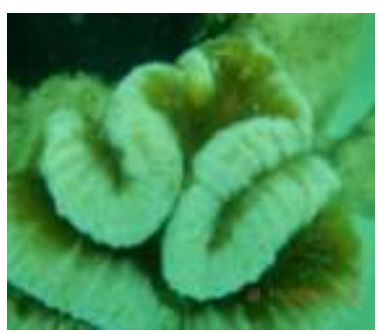

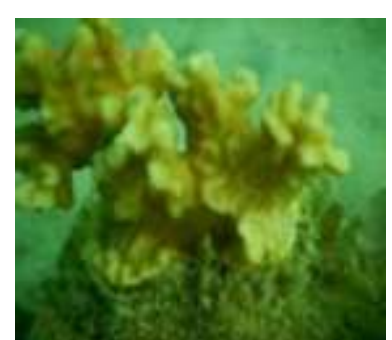

Leptoseris papyracea

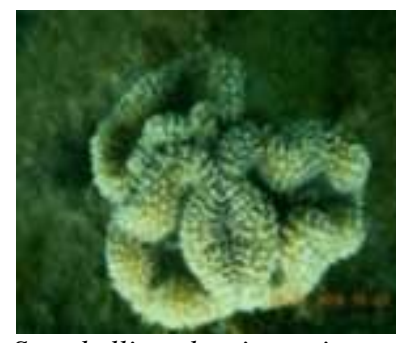

Symphyllia valenciennesi

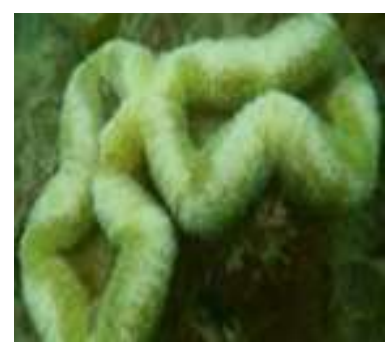

Symphyllia sp2

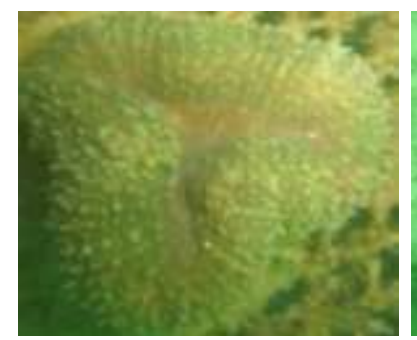

Australomussa rowleyensis

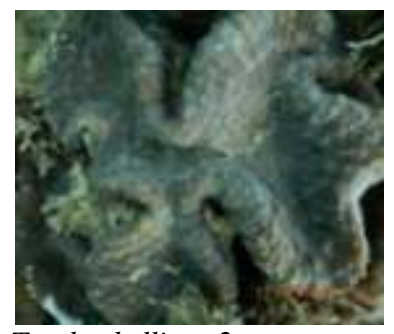

Trachyphyllia sp2

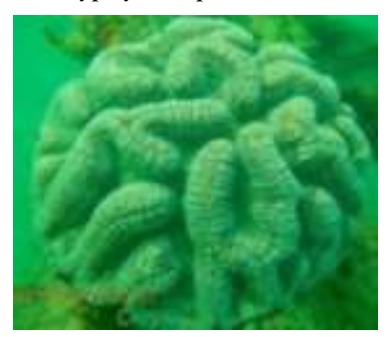

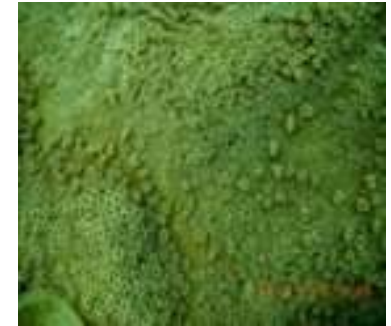

Alveopora spongiosa

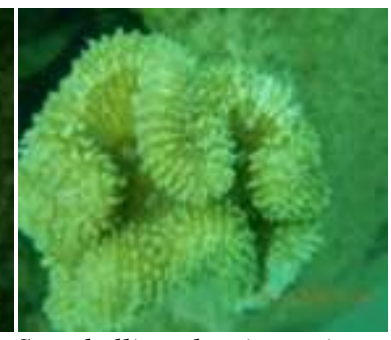

Symphyllia valenciennesi

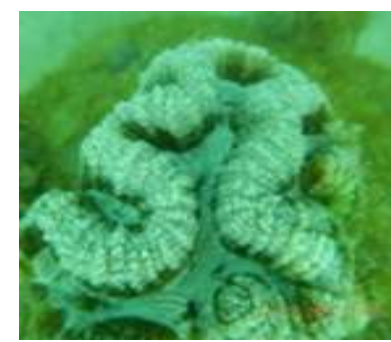

Symphyllia sp3

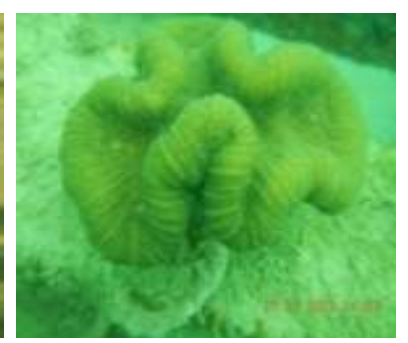

Trachyphyllia spl

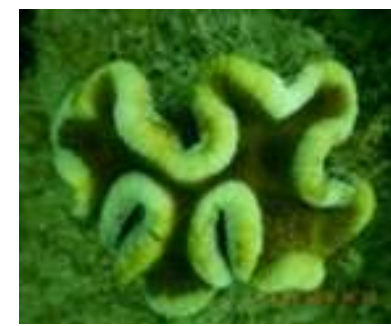

Trachyphyllia sp3

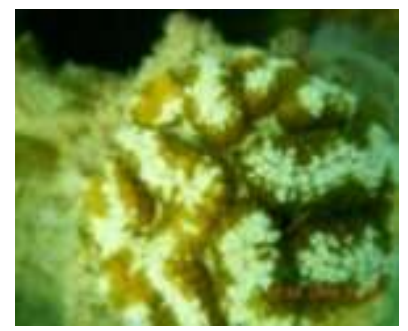




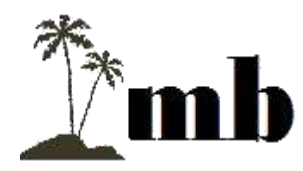

Minda Baharu, Volume 3, No 1 Juli 2019

Doi. 10.33373/jmb.v3i1.1862

https://www.journal.unrika.ac.id/index.php/MNDBHRU

P-ISSN 2656-0631; E-ISSN 2614-5944

Hal. 42-58

Lobophyllia hataii

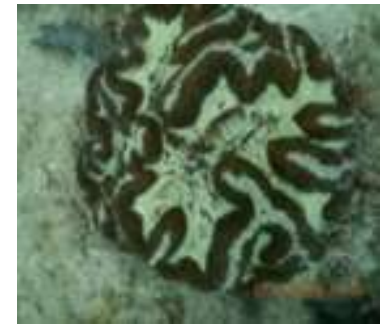

Lobophyllia sp2

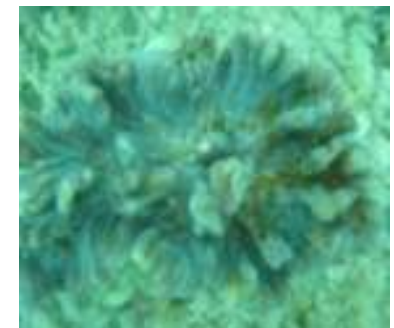

Pectinia paeonia

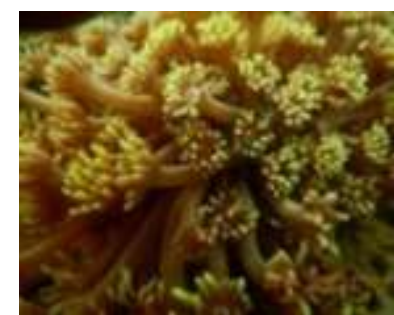

Goniopora lobata

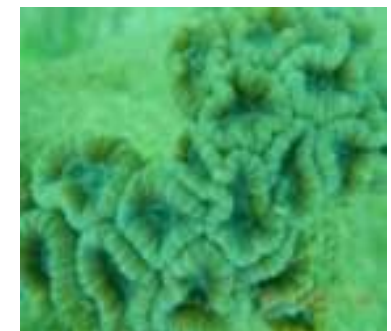

Caulastrea furcata

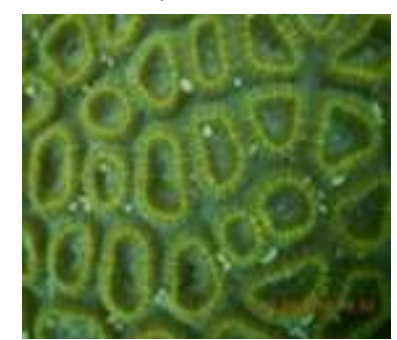

Montastrea valenciennesi
Lobophyllia flabelliformis

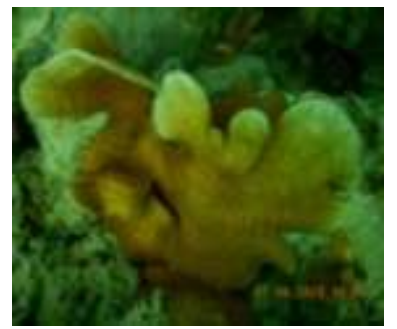

Pavona cactus

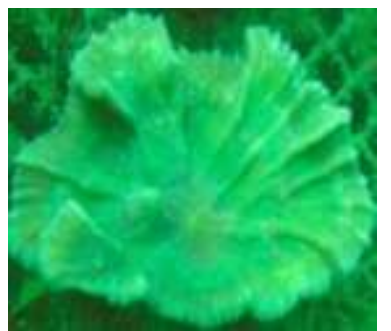

Pectinia spl

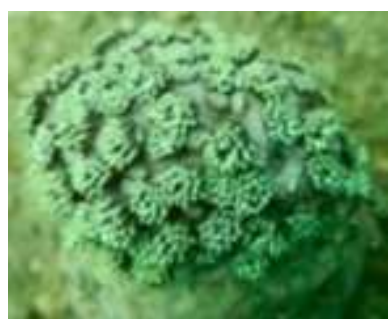

Goniopora stutchburyi

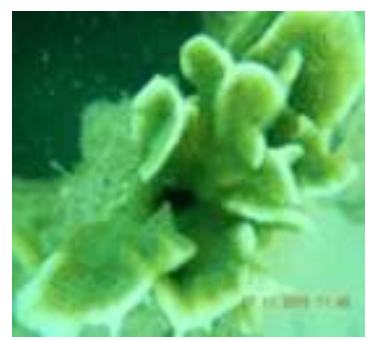

Pavona decussata

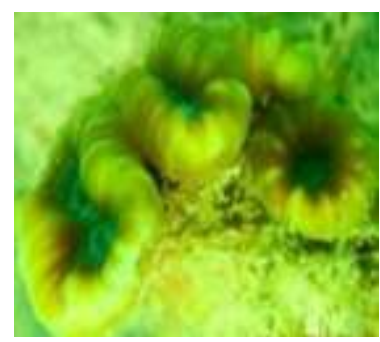

Caulastrea tumida

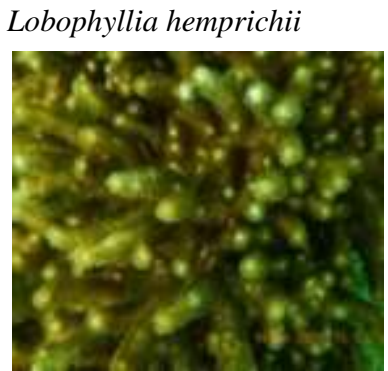

Seriotopora caliendrum

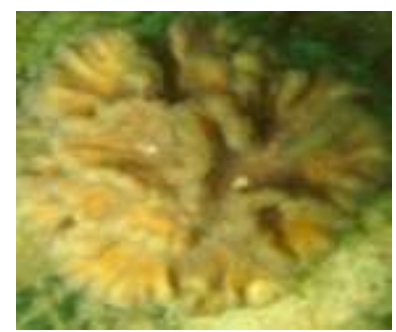

Pectinia $s p 2$

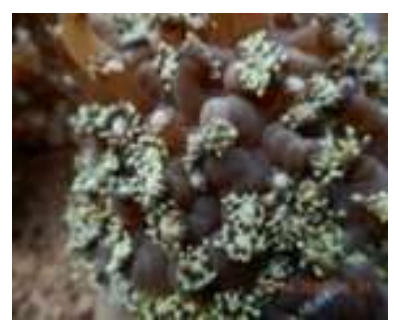

Goniopora pandoraensis

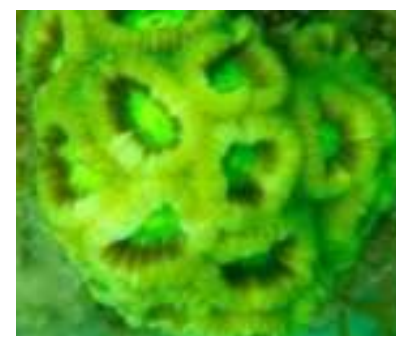

Favia albidus

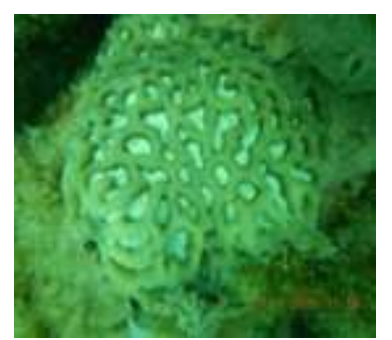

Acanthastrea hillae
Lobophyllia spl

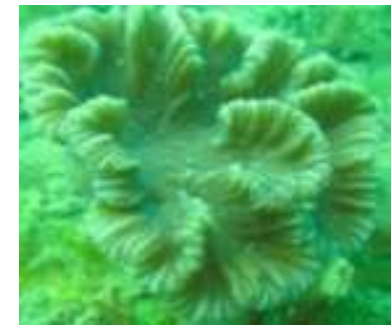

Pectinia lactuca

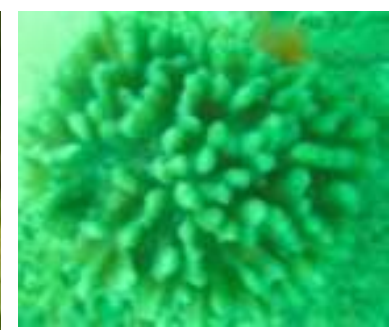

Pectinia sp2

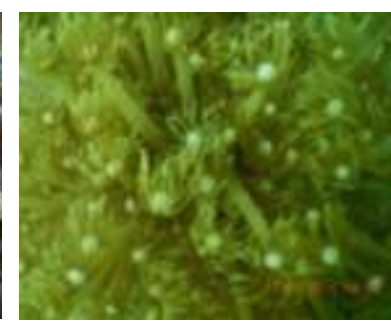

Goniopora sp1

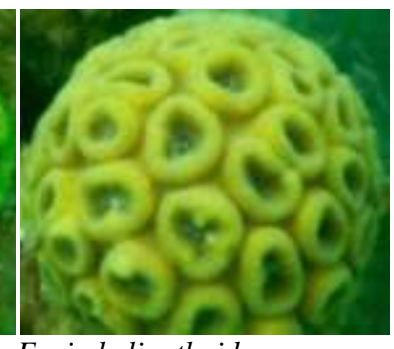

Favia helianthoides

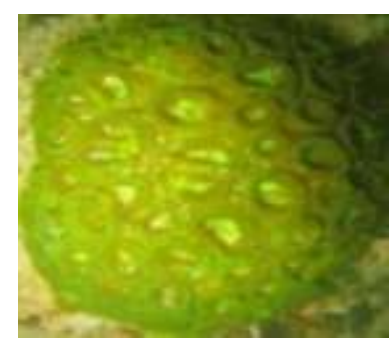

Acanthastrea echinata 


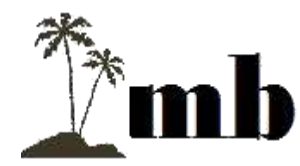

Minda Baharu, Volume 3, No 1 Juli 2019

Doi. 10.33373/jmb.v3i1.1862

Hal. 42-58

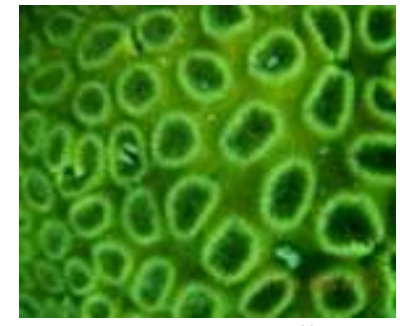

Montastraea magnistellata

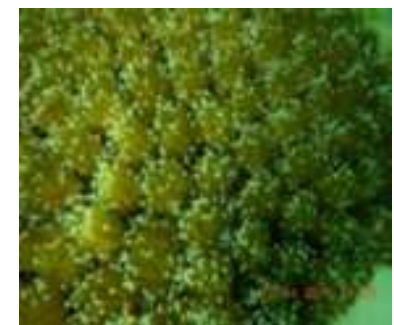

Galaxea sp1

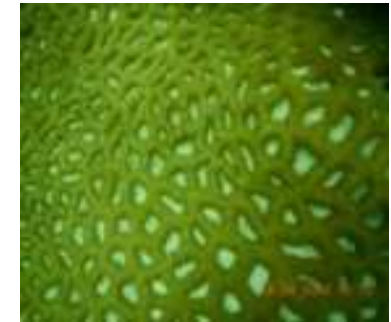

Goniastrea australiensis

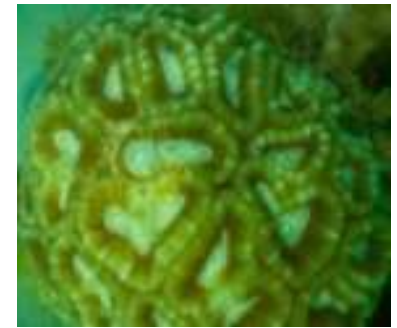

Favia maxima

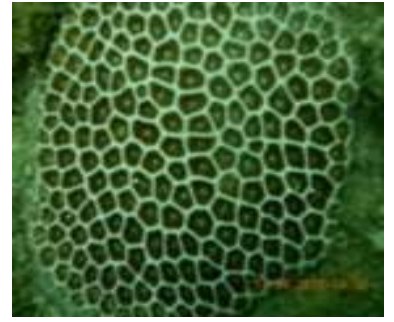

Pseudosiderastrea tayami

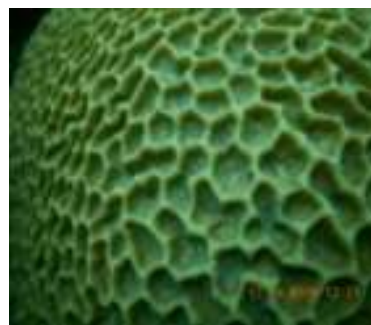

Goniastrea favulus

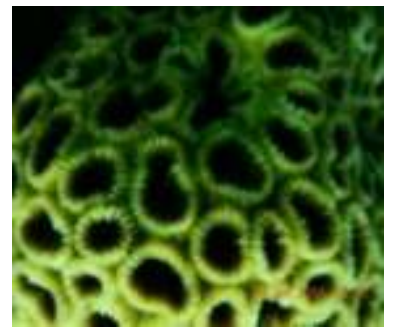

Favia lizardensis

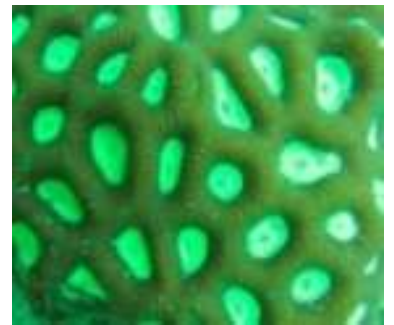

Favia abdita

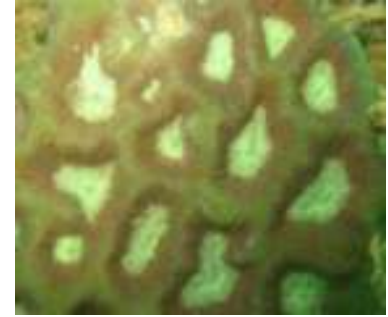

Oulophyllia bennettae

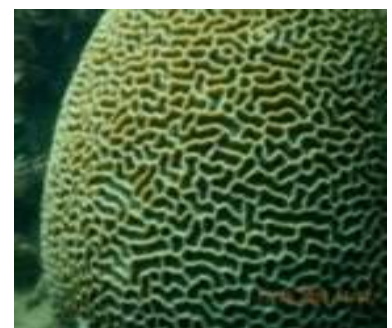

Goniastrea favulus

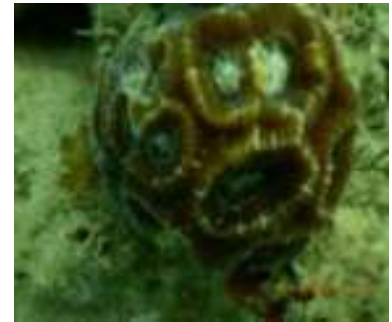

Favia rotundata

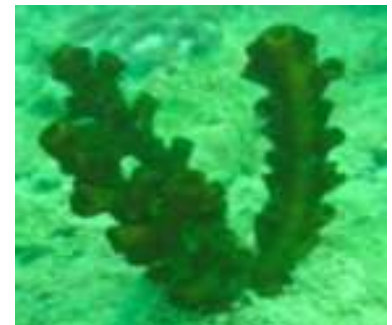

Tubastrea micrantha

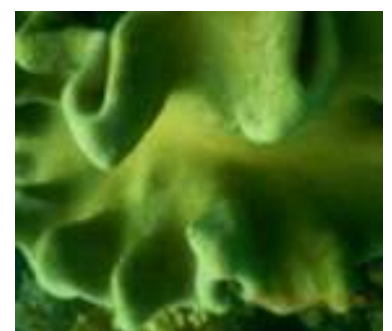

Sarcophyton trocheliphorum

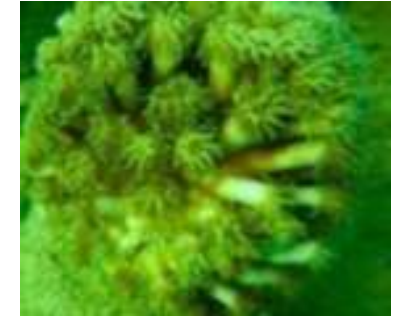

Galaxea fascicularis

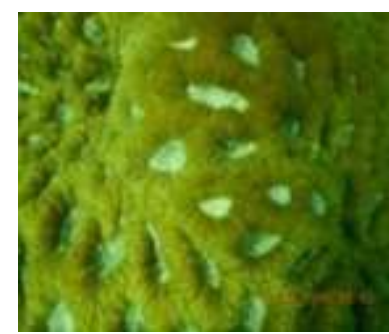

Goniastrea aspera

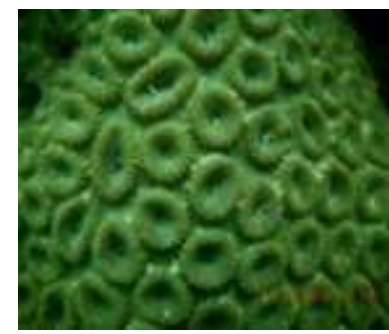

Favia speciosa

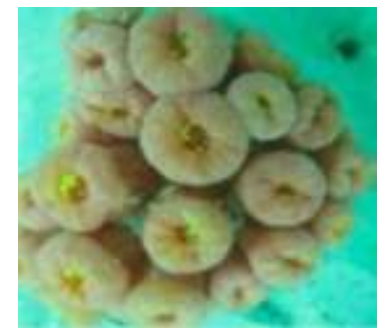

Tubastrea faulkneri

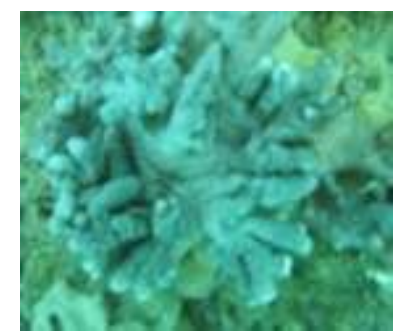

Cladiella sp2
Cladiella sp1
Sphaerella krempfi

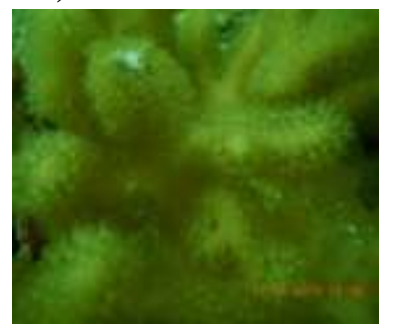

-

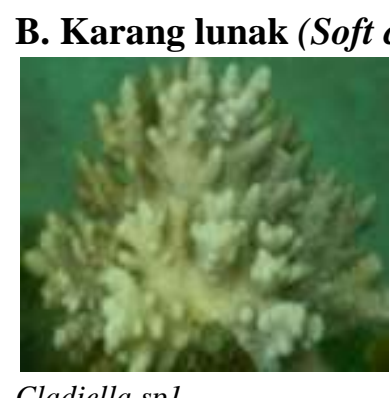


Doi. 10.33373/jmb.v3i1.1862

Minda Baharu, Volume 3, No 1 Juli 2019

P-ISSN 2656-0631; E-ISSN 2614-5944

https://www.journal.unrika.ac.id/index.php/MNDBHRU

Hal. 42-58

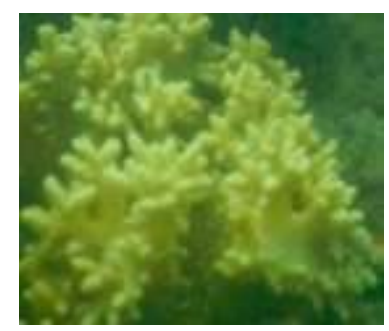

Sphaerella krempfi

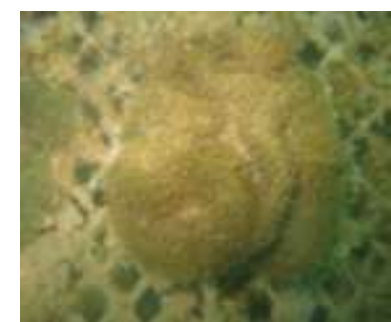

Ricordia $s p 2$

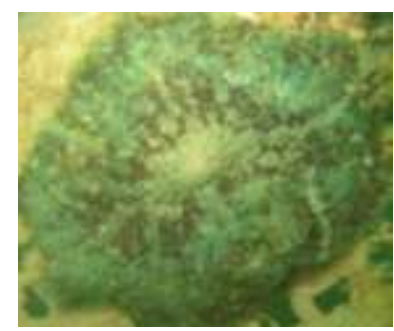

Rhodactis mushroom

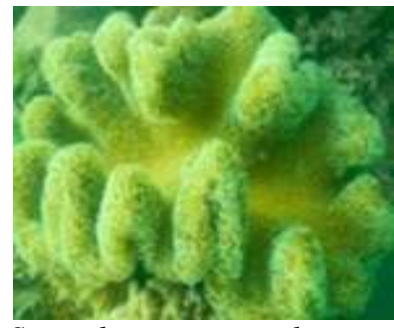

Sarcophyton acutangulum

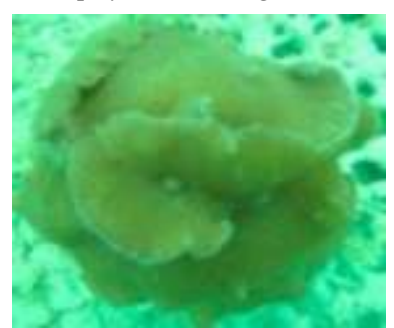

Discosoma sp

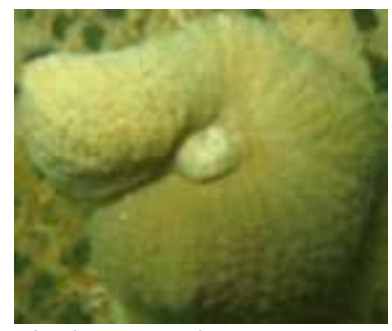

Rhodactis mushroom

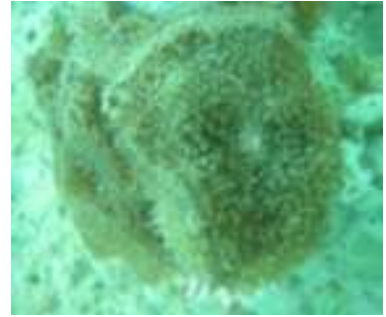

Ricordia yuma

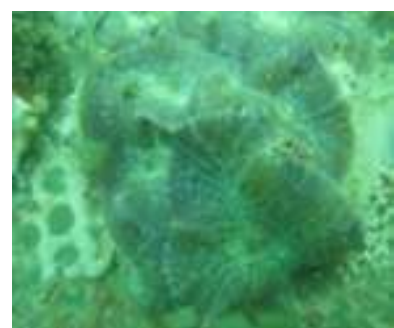

Actinodiscus $s p$

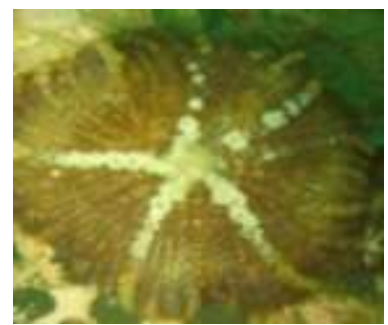

Rhodactis mushroom

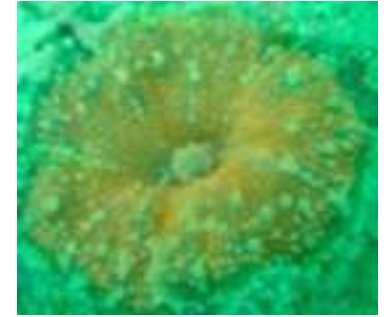

Ricordia $s p 1$

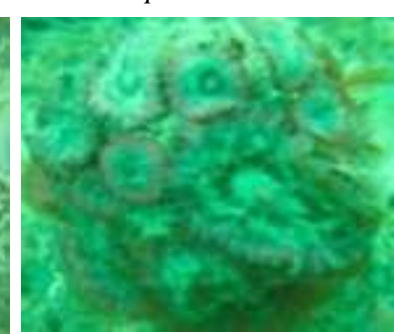

Actinodiscus $s p$ 